\title{
The Ornithodoros hasei (Schulze, 1935) (Acari: Argasidae) species group in Argentina
}

\author{
SANTIAGO NAVA ${ }^{1}$, JOSÉ M. VENZAL ${ }^{2}$, M. MÓNICA DÍAZ ${ }^{3,4}$, ATILIO J. MANGOLD ${ }^{1} \&$ \\ ALBERTO A. GUGLIELMONE ${ }^{1}$ \\ ${ }^{1}$ Instituto Nacional de Tecnología Agropecuaria, CC 22, CP 2300 Rafaela, Santa Fe, Argentina. \\ E-mail: aguglielmone@rafaela.inta.gov.ar \\ ${ }^{2}$ Departamento de Parasitología Veterinaria, Facultad de Veterinaria, Universidad de la República, Av. Alberto Lasplaces \\ 1550, CP 11600 Montevideo, Uruguay \\ ${ }^{3}$ Consejo Nacional de Investigaciones Científicas y Técnicas. Facultad de Ciencias Naturales e Instituto Miguel Lillo, Uni- \\ versidad Nacional de Tucumán, San Miguel de Tucumán (4000), Argentina \\ ${ }^{4}$ PIDBA (Programa de Investigaciones de Biodiversidad Argentina), Universidad Nacional de Tucumán, Argentina
}

\begin{abstract}
Six larvae of the genus Ornithodoros were collected in Rio Lavayén, approximately $1 \mathrm{~km}$ north of Santa Rita, San Pedro Department (24 $\left.28^{\prime} \mathrm{S}, 64^{\circ} 48^{\prime} \mathrm{W}\right)$, Jujuy Province, Argentina, on three species of bats: Molossops temminckii (Burmeister, 1854) (Molossidae), Myotis albescens (E. Geoffroy, 1806) (Vespertilionidae) and Histiotus laephotis Thomas, 1916 (Vespertilionidae). All six larvae were identified as belonging to the Ornithodoros hasei species group, whose members are common parasites of bats throughout the Neotropical Zoogeographic Region. This is the first record of the O. hasei species group in Argentina, and M. temminckii and $H$. laephotis are new hosts for this tick. Studies of the morphology, genetics and ecology of $O$. hasei across its vast range will be necessary in order to determine whether sibling species are present.
\end{abstract}

Key words: Argasidae, Ornithodoros hasei, bats, Argentina

\section{Introduction}

Ornithodoros hasei (Schulze, 1935) is a widely distributed bat parasite in the Neotropical Zoogeographic Region, with records from southern Mexico to Uruguay (Guglielmone et al. 2003). Klompen \& Oliver (1993) classified this tick in the genus Carios, a position supported by Horak et al. (2002) but questioned by Guglielmone et al. (2005). We have elected to follow Hoogstraal's (1985) classification until the systematic position of this species is clarified. Major collections of $O$. hasei were made in Venezuela by Jones et al. (1972), who found morphological variation among ticks collected from different localities, and stated that specimens identified as $O$. hasei may represent more than one species.

To date, only three species of Ornithodoros have been reported from Argentina: O. rostratus Aragão, 1911, O. talaje (Guérin-Méneville, 1849) and O. mimon Kohls, Clifford and Jones, 1969 (Gugliemone et al. 2003; Venzal et al. 2004). Here we report the first Argentinean records of ticks belonging to the $O$. hasei group, collected on three species of bats.

\section{Materials and methods}

Six ticks of the genus Ornithodoros were collected on bats by M. Mónica Díaz in Rio Lavayén, 
approximately $1 \mathrm{~km}$ north of Santa Rita, San Pedro Department ( $\left.24^{\circ} 28^{\prime} \mathrm{S}, 64^{\circ} 48^{\prime} \mathrm{W}\right)$, Jujuy Province, Argentina: 1 larva (field number: MMD 228), ex Molossops temminckii (Burmeister, 1854) (Molossidae), Oct. 05, 1995; 1 larva (field number: MMD 214), ex M. temminckii, Oct. 04, 1995; 1 larva (field number: MMD 227), ex Myotis albescens (E. Geoffroy, 1806) (Vespertilionidae), Oct. 06, 1995; 2 larvae (field number: MMD 212), ex Histiotus laephotis Thomas, 1916 (Vespertilionidae), Oct. 04, 1995; 1 larva (field number: MMD 234), ex M. albescens, Oct. 06, 1995. The ticks were slide-mounted in Hoyer's medium, identified using the keys and descriptions of Kohls et al. (1965) and Jones \& Clifford (1972), and deposited in the annexes of the Colección Mamíferos Lillo (CML), Universidad Nacional de Tucumán, Tucumán, Argentina.

\section{Results and discussion}

The six larvae were found to belong to the $O$. hasei species group. Their morphology was homogeneous. Larvae of $O$. hasei can be separated from those of other Ornithodoros parasites of bats by the following characters: hypostome tapers to a point, with dentition $3 / 3$ along anterior two-thirds and $2 / 2$ posteriorly to base, file 1 with $16-18$ denticles, 2 with $15-18$, and 3 with $8-12$; dorsal plate pyriform, narrow $(132 \mu-150 \mu)$, length less than $250 \mu$; and distance between anterolateral setae less than $0.100 \mu$. Measurements of our specimens appear in Table 1, alongside those presented by Kohls et al. (1965) to describe the larva of $O$. hasei. The only significant difference between Argentinean specimens and those of Kohls et al. (1965) lies in the length of the basis capituli, which is shorter in Argentinean larvae.

These specimens constitute the first records of the $O$. hasei species group from Argentina. Elsewhere, $O$. hase $i$ has been found on a total of 29 species of bats and on one sigmodontine rodent (Cooley \& Kohls, 1944; Kohls et al. 1965; Fairchild et al. 1966; Morel, 1967; Kohls, 1969; Jones et al. 1972; Marinkelle \& Grose, 1981). Two of the hosts examined in this study, M. temminckii and $H$. laephotis, are new for this tick species. This new record of $O$. hasei in Argentina is not unexpected, since $O$. hasei is present in neighboring Brazil, Bolivia and Uruguay (Guglielmone et al. 2003).

Several members of the genus Ornithodoros are known to be associated with bats. However, in Argentina, where 60 bat species have been recorded (Barquez 2006), only O. mimon has been found parasitizing this order of mammals (Venzal et al. 2004). This is probably due to poor sampling of Argentinean bats rather than an absence of tick parasitism.

As noted above, morphological dissimilarity among larvae of $O$. hasei from different Venezuelan localities has been established (Jones et al. 1972). It is unclear whether this is related to the existence of sibling species or to intraspecific variation. Comparative morphological, genetic and ecological studies of $O$. hasei throughout its vast Neotropical range may help to resolve this issue.

\section{Acknowledgements}

We acknowledge the support of INTA and the Asoc. Coop. INTA Rafaela to SN, AAG and AJM.

Fieldwork was supported by grants from CONICET (Consejo de Investigaciones Científicas y

Técnicas, Argentina) and CIUNT (Consejo de Investigaciones de la Universidad Nacional de Tucumán, Argentina) with the collaboration of the members of PIDBA (Programa de Investigaciones de Biodiversidad Argentina) and its director Dr. Rubén Barquez. 
TABLE 1. Comparative measurements of larvae belonging to the Ornithodoros hasei species group.

\begin{tabular}{|c|c|c|}
\hline & Argentinean $^{*}$ & Kohls et al. (1965) \\
\hline Scutal length & $235-247.5 \mu$ & $220-240 \mu$ \\
\hline Scutal width & $132.5-150 \mu$ & $127-150 \mu$ \\
\hline Dorsal setae (number of pairs) & 19 (15 dorsolateral; 4 central) & $\begin{array}{l}\text { 17-20 (14-15 dorsolateral; 3-5 } \\
\text { central) }\end{array}$ \\
\hline Anterolateral dorsal setae (distance) & $75-95 \mu$ & $98 \mu$ (average) \\
\hline Posterolateral dorsal setae (distance) & $70-85 \mu$ & $75 \mu$ (average) \\
\hline Ventral setae (number of pairs) & 8 & 8 \\
\hline Ventral setae circumanal 1 & $37.5-47,5 \mu$ & $44 \mu$ (average) \\
\hline Ventral setae circumanal 2 & $50-52.5 \mu$ & $60 \mu$ (average) \\
\hline Ventral setae circumanal 3 & $67.5-75 \mu$ & $78 \mu$ (average) \\
\hline Length of basis capituli & $130-137.5 \mu$ & $153-190 \mu$ \\
\hline Width of basis capituli & $175-200 \mu$ & $170-234 \mu$ \\
\hline Posthypostomal setae 1 (distance) & $20 \mu$ & $20 \mu$ (average) \\
\hline Posthypostomal setae 2 (distance) & $70-85 \mu$ & $76 \mu$ (average) \\
\hline Palpal length & $225-240 \mu$ & $208-252 \mu$ \\
\hline Palpal width & $37,5 \mu$ & $38-44 \mu$ \\
\hline Palpal article I (length) & $55-62.5 \mu$ & $62 \mu$ (average) \\
\hline Palpal article II (length) & $70-75 \mu$ & $72 \mu$ (average) \\
\hline Palpal article III (length) & $62.5-65 \mu$ & $64 \mu$ (average) \\
\hline Palpal article IV (length) & $40-45 \mu$ & $41 \mu$ (average) \\
\hline Palpal setae article I & 0 & 0 \\
\hline Palpal setae article II & 4 & 4 \\
\hline Palpal setae article III & 5 & 5 \\
\hline Palpal setae article IV & 9 & 9 \\
\hline Hypostome length (toothed portion) & $160-162.5 \mu$ & $135-182 \mu$ \\
\hline Hypostome width & $47.5-57.5 \mu$ & $49-61 \mu$ \\
\hline Apical dental formula & $3 / 3$ & $3 / 3$ \\
\hline Median dental formula & $3 / 3$ & $3 / 3$ \\
\hline Basal dental formula & $2 / 2$ & $2 / 2$ \\
\hline Denticles row 1 & 16 & $16-18$ \\
\hline Denticles row 2 & 15 & $15-18$ \\
\hline Denticles row 3 & 12 & $8-12$ \\
\hline
\end{tabular}

* Ranges based on 3 to 6 specimens.

\section{References}

Barquez, R.M. (2006) Orden Chiroptera. In: Barquez, R.M., Díaz, M.M. \& Ojeda, R.A. (eds.) Los mamíferos de Argentina: sistemática y distribución. Mastozoología Neotropical. Publicaciones Especiales, SAREM. pp. 56-87. 
Cooley, R.A. \& Kohls, G.M. (1944) The genus Amblyomma (Ixodidae) in the United States. Journal of Parasitology, 30, 77-111.

Fairchild, G.B., Kohls, G.M. \& Tipton, V.J. (1966) The ticks of Panama (Acarina: Ixodoidea). In: Wenzel, R.L. \& Tipton, V.J. (eds.) Ectoparasites of Panama. Field Museum of Natural History, Chicago, pp. 167-219.

Guglielmone, A.A., Estrada-Peña, A., Keirans, J.E. \& Robbins, R.G. (2003) Ticks (Acari: Ixodida) of the Neotropical zoogeographic region. Spec. Publ. Int. Cons. Ticks Tick-Borne Dis., Atalanta, Houten, The Netherlands. $173 \mathrm{pp}$.

Guglielmone, A. A., Mangold, A. J. \& Estrada-Peña, A. (2005) Are Antricola species proper representatives of the genus Carios? Newsletter on Ticks and Tick-Borne Diseases of Livestock in the Tropics, 27, 42-43.

Horak, I.G., Camicas, J.L. \& Keirans, J.E. (2002) The Argasidae, Ixodidae and Nuttalliellidae (Acari: Ixodida): a world list of valid tick names. Experimental and Applied Acarology, 28, 25-54.

Hoogstraal, H. (1985) Argasid and nuttalliellid ticks as parasites and vectors. Advances in Parasitology, 24, $135-238$.

Jones, E.K. \& Clifford, C.M. (1972) The systematics of the subfamily Ornithodorinae (Acarina: Argasidae). V. A revised key to larval Argasidae of the Western Hemisphere and description of seven new species of Ornithodoros. Annals of the Entomological Society of America, 65, 730-740.

Jones, E.K., Clifford, C.M., Keirans, J.E. \& Kohls, G.M. (1972) The ticks of Venezuela (Acarina: Ixodoidea) with a key to the species of Amblyomma in the Western Hemisphere. Brigham Young University, Science Bulletin, Biological Series, 17, 1-40.

Klompen, J.S.H. \& Oliver, J.H. (1993) Systematic relationships in the soft ticks (Acari: Ixodida: Argasidae). Systematic Entomology, 18, 313-331.

Kohls, G.M. (1969) New records of ticks from the Lesser Antilles. Studies on the Fauna of Curaçao and other Caribbean Islands, 28, 126-134.

Kohls, G.M., Sonenshine, D.E. \& Clifford, C.M. (1965) The systematics of the subfamily Ornithodorinae (Acarina: Argasidae). II. Identification of the larvae of the Western Hemisphere and description of three new species. Annals of the Entomological Society of America, 58, 331-364.

Marinkelle, C.J. \& Grose, E.S. (1981) A list of ectoparasites of Colombian bats. Revista de Biologia Tropical, 29, 11-20.

Morel, P.C. (1967) Les tiques des animaux sauvages des Antilles (Acariens, Ixodoidea). Acarologia, 9, 341352.

Venzal, J.M., Autino, A.G., Nava, S. \& Guglielmone, A.A. (2004) Ornithodoros mimon Kohls, Clifford \& Jones, 1969 (Acari: Argasidae) on Argentinean bats, and new records from Uruguay. Systematic and Applied Acarology, 9, 37-39.

Accepted by Richard G. Robbins: 31 Jan. 2007 